\section{IJ§ER}

ISSN: 2149-5939
International Journal of Social Sciences and Education Research

Online, http://dergipark.gov.tr/ijsser

Volume: 3(4), 2017

\title{
Sociology in cinema: Origins of social types in Turkish cinema ${ }^{1}$
}

\author{
Çiçek Coşkun ${ }^{2}$
}

Received Date: 05 /04 / $2017 \quad$ Accepted Date: 14 /06 / 2017

\begin{abstract}
There is a strong relationship between the social type concept in sociology and cinema. We can see representations of various social types in cinema films. Aim of this study is to examine the relationship between the social type concept in sociology and origins of social types in classically narrated Turkish films. After a general introduction, social type concept in sociology will be discussed first. Second, classical narrative structure will be examined. Then, we will examine character and type in cinema films. Finally, we will examine origins of social types in Turkish cinema.
\end{abstract}

Keywords: social types, cinema, Turkish cinema

\section{Introduction}

In various forms of thought, sociology has been taken as a discipline that provides knowledge about modern social life; and this knowledge can be used for prediction and control (Giddens, 1990, p.15). Social type is an important concept in sociology in order to provide knowledge about modern social life. Creation and examination of social types in the society started with Herbert Spencer and reached its peak with Simmel (think 'stranger' and 'poor') (Baker, 2002, p.2). Although Simmel did not make a specific definition of social type, his usage of social type is a very important contribution in sociology. Actually, lots of social scientists and artists examine and use social types in their works. Simmel's 'Poor' and 'Stranger', Marx's 'Lumpen Proleteriats', Foucault's 'Mads', Mills' 'Power Elite' or 'White Collar' are examples of social types in social sciences; and Moliere's 'L'Avare', Balzac's 'Pere Grandet' and Chaplin's 'The Tramp' are examples of social types in literature and cinema (Baker, 2002, pp.52-71). Social types allow us to use our senses and think intuitively (Baker, 2002).

If we try to define social type in light of these, we face with different definitions in literature. For instance, according to Booth and Blair (1989, p.236), social types are "unconventional roles in a sociocultural system (i.e., those not defined in terms of major social institutions but well known in everyday life)" such as hippies, street people and highbrows. According to Strong (1943, p.563), social types are "constructs which the group arrives at by selecting or abstracting accentuated forms of conduct displayed by some of its members and having specific connotations in terms of the interests, concerns, and dispositions of the group." Glick (1955, p.241) defines social type as "a process of categorizing and labeling commonly occurs, with the result that persons making certain type-responses, often carried out in an accentuated manner, come to be

\footnotetext{
${ }^{1}$ A shorter version of this subject was presented at International Conference on Arts, Education and Social Science, 14-15 November 2016.

2 Assist. Prof. Dr., Baskent University, Ankara/TURKEY, ccoskun@baskent.edu.tr
} 
Coşkun, Ç. (2017). Sociology in cinema: Origins of social types in Turkish cinema. International Journal of Social Sciences and Education Research,3 (4), 1147-1154.

'typed' by being associated with a particular label." If we make a general definition for the social type concept in light of the above, we can define social type according to Almog (1998),

I therefore define social type as a human prototype-a sociological summary of th e typical characteristics of a particular group or of a category of human beings usually recognized and typed by the public and often granted a nickname. This group or category may be a secondary group, a community, a profession, a subculture, a status group, a class or a generation unit that is characterized by its look (physical, fashionable or both), life style and philosophy, pattern of interaction (particularly linguistic), attitudes and certain psychological traits. Sociological imagination, developed by C. W. Mills, is an important concept at that point. According to Mills, the main idea of sociological imagination is to be able to study the relationship between individual lives and larger social concepts and to changeover from one status to the other without losing perspective of both (Mills, 1959). We need sociological imagination in order to understand social types in a society. On the other hand, sociological imagination takes us to another point where sociology and imagination can be used effectively: Cinema films. Narrative structure, genre and characters are main elements of the story that define a film's structure and components. If we use sociological imagination in such a film, we see that there is a connection between the storyline of the film and the society in which that film was shot. Besides, audience easily identifies with and understands the story of the film in character centered narrative structure.

If we look for the connection of classical narrative structure and sociological imagination, we can make this connection throughout social types. We see representation of social types almost in every film which has a classical narrative structure. Actually, social types and narration in a film led the audience to identify themselves with the story and characters. A situation that led us to identify with is catchy. That's why cinema films stick our minds more than a didactical text. On the other hand, we can express that cinema makes social types visible for us. If we can use sociological imagination at that point, it' $\mathrm{d}$ be possible to understand the relations between cinema films and society.

When we look at Turkish cinema from this point forth, we can state that, films with a classical narrative structure represent social types and we can find the connection between social types in Turkish films and Turkish society throughout sociological imagination. Thus, examination of origins of social types in Turkish cinema is important in order to understand this structure.

\section{Classical narrative structure and social types}

Philosophers have been interested in classical narrative structure from the very beginning. For instance, Aristotle mentions the parts of tragedy in his Poetika. According to him, tragedy is divided into separate parts, "namely, Prologue, Episode, Exode, Choric song; this last being divided into Parode and Stasimon" (Aristotle, 1997, p. 21). These parts are common to all plays, and they generate integrity. If we look at narrative structure from an Aristotelian point of view, we see that "the imitation of actions of the real world is 'praxis', their formation of an argument is 'logos' and the units that formed the plot is 'mythos"” (Chatman, 1978, p.19). Roland Barthes, Claude LéviStrauss, Tzvetan Todorov and Vladimir Propp are among important narrative theorists. We can summarize their theories in order to understand narrative structure.

Barthes states that all narratives have some common structures. Although there are differences between individual narratives, all narratives have a number of common structures that affect our reading and perception of the texts (Barthes, 1974). Barthes defines five codes. Action Code (An 
Coşkun, Ç. (2017). Sociology in cinema: Origins of social types in Turkish cinema. International Journal of Social Sciences and Education Research,3 (4), 1147-1154.

action implies a further narrative action), Cultural/Reference Code (Anything in a narrative is in a strong connection with the cultural features of people), Semantic code (An element in a text has additional meanings by way of connotation), Symbolic Code (An element in a text can symbolize another thing), Enigma Code (There are elements in a text that are not explained, which creates an enigma for the reader/audience) (Barthes, 1974).

Materials of cinema are five-fold. Two of them are visual (images and graphic marks) and three of them are auditory (dialogues, music and noise) (Olivier, 2009, p.20). Those five materials generate 'movement' and 'time' in cinema, and they form a story on the screen. At that point narrative comes into play. It is 'how' a film is narrated, rather than 'what' is narrated, that makes the difference.

Another important narrative theorist is Claude Lévi-Strauss. He writes that stories unconsciously mirror the values and myths of a culture. Those values and myths are stated through binary oppositions, which mean we can understand and measure all phenomenon through their opposites such as right and wrong, light and dark, love and hate (Lévi-Strauss, 1955, p.428-444).

Todorov defines the classical narrative structure. According to him, the environment within a story is in a state of calm at first. Secondly, the calm environment is disrupted by an event. Thirdly, recognition of that disruption comes. Fourthly, an attempt to solve the problem and to repair the disruption is made. Finally, peace is restored again and new equilibrium comes (Todorov and Weinstein, 1969, p.70-76). On the other hand, Vladimir Propp stated that characters in stories act as narrative functions and drive the plot forward (Propp, 1969).

In light of all of this, we can state that narrative is the style of storytelling within a system of cause-effect and time-space relation. Narrative can have a linear structure in which the story is told in a chronological order, or a non-linear structure in which the story is not told in a chronological order. We can state that there are different types of narrative structures such as classical narrative with a chronological or linear structure, multi narrative, flashbacks, fragmented narrative and metafictive. We will focus on classical narrative structure since the films selected for the present story are in a classical narrative structure within a linear form.

Classical narrative, as described by Todorov, has three elements: 'exposition, climax and resolution'. The exposition introduces the viewer to the principal characters and their personas and the space or environment that the story's characters inhabit (Butler, 2014). In the climax part a conflict that needs a resolution appears. Finally, in the resolution part, the conflict and enigmas are solved and stability comes (Butler, 2014). We mostly see a linear cause-effect relationship order, sometimes with flashbacks, in a classical narrative structure.

We can find the same elements and a similar structure in classical film narrative. "The main characteristic of the classical film narrative is that the ambiguity and uncertainty that it creates are subject to qualitative restrictions; the narration is as straightforward as possible" (Tan, 1996, p.8). There is a cause-effect and time-space relationship within a moving image; and the same three stages, 'exposition, climax and resolution', are present. Actually, classical films are likely to have the central principle of causal linearity (Bordwell, Staiger and Thompson, 1988, p. 22).

"Narrative film consists of three systems: narrative logic (definition of events, causal relations and parallelisms between events), the representation of time (orders, duration, repetition), and the representation of space (composition, orientation etc)" (Bordwell, Staiger and Thompson, 1988, 
Coşkun, Ç. (2017). Sociology in cinema: Origins of social types in Turkish cinema. International Journal of Social Sciences and Education Research,3 (4), 1147-1154.

p.11). Any given technical method creates meanings and helps the development of story and characterization. Scales of shots, camera movements, camera angles, lighting, music and editing are among the tools of meaning making in cinema. For instance, 'pan' and 'tilt' movements are classical camera movements for recognition of environment and characters. A high camera angle gives us the impression that the character in the shot is not powerful enough or failing while a low camera angle gives the reverse impression. Or, dramatic music can create high tension for the audience; and upbeat music can create excitement or expectation. At this point, we can mention Béla Balázs. According to Balázs, the basic principle of the theatre is the spectator's ability to see the played scene as a whole. The second principle is that the spectator sees the whole stage from a distance where he/she sits. This distance is fixed. The third basic principle of the theatre is that the spectator's angle of seeing the stage is also always the same and fixed (Balázs, 1952, p.30). Cinema changes these three basic principles of the theatre. With cinema, the distance between the spectator and a scene can vary, even over the course of a single scene. This is because scenes in film can be divided into different shots. Also, because there are changing camera angles in film, the distance between the spectator and the scene and the spectators' angle of vision changes. Finally, with the affect of montage/editing in film, "the whole scene is composed of a mosaic of frames aligned as if it were in chronological sequence" (Balázs, 1952, p. 31). These elements of cinema compose a moving image as reflections of real life. Thus, film narrative gives us a different structure, which can create a fictional world that represents real world.

All in all, we should state that the most important and powerful part of fictional narratives is their relation with reality. Films, especially the classical films, allow the audience a privileged position in a fictional world (Bordwell, Staiger and Thompson, 1988, p.23). The camera becomes not only the storyteller but the audience as well, and the narrator is replaced by the 'ideal observer' (Bordwell, Staiger and Thompson, 1988, p.56). Thus, the audience sees the fictional events in the film as if they were happening around them; as if the fictional events are real (Tan, 1996, p. 53). Because of this reality illusion, the story that is told and the characters that are created for the story are very important for the audience. The audience gets in touch with the filmic reality and establishes empathy through the story and characters. Thus, reality effect and character creation are two important elements of cinema.

\section{Character as a social type in cinema films}

The notion of cinema is telling a story by representing real life. Characters have an important position in this process. Characters of a film represent reflections of people from reality. In other words, we find a projection of reality in films. Because of this reality connection, we can state that characters of films can represent social types.

In a classical narrative structure, characters and their relationship with each other are the main elements of the story that construct causality. Actually, "Character-centered -i.e., personal or psychological — causality is the armature of the classical story" (Bordwell, Staiger and Thompson, 1988 , p. 12). When we look at character types in main character theories, we can find that they argue that almost all stories represent some particular characteristics. Therefore, stories represent social types.

For instance, Propp determines eight main character types in one hundred tales he examined (Propp, 1969). These are, 'the hero', 'villain' (is against the hero), 'the dispatcher' (is the one who sends the hero on a journey for struggle in order to restore the equilibrium), 'donor' (is a 
Coşkun, Ç. (2017). Sociology in cinema: Origins of social types in Turkish cinema. International Journal of Social Sciences and Education Research,3 (4), 1147-1154.

provider who gives a magical object to the hero and prepares him to struggle), 'the magical helper' (helps the hero during the struggle), 'the false hero' (is the one who seems on the same side with hero in the beginning but turns out to be against him in the end), 'the princess/the heroine' (is the one who the hero looks to save during the narrative and marries at the end), and 'the father' (princess' father, who also can be the dispatcher in some stories) (Propp, 1969). We can find a similar classification, based on types, in Goffman's work. According to him, the main characters in a performance are 'the protagonist' (leading character), 'The deuteragonist' (secondary character), 'the bit player' (minor character whose past is in an enigma) and 'the fool' (character that gives the humor to the story) (Goffman, 1959). There are character typologies in digital games too. For instance, Bartle makes a typology of characters in digital games. According to him, there are 'achievers', 'explorers', 'socializers' and 'killers' that are characters in a game (Bartle, 1996). In another theory developed for online communities (Campbell, Fletcher and Greenhill, 2009) types are presented as 'the big man', 'the sorcerer' and 'the trickster'. From this point forth, we can state that similar character classifications could be done for films. Films also represent character typologies and social types.

In light of this, we can state that literature and cinema use some character typologies in their stories. At this point, we can express a connection between fictional stories and social types. As we examined above, sociologists have been interested in social types since Spencer first put forth social types and Mills analyzed them in detail. We can obtain knowledge about a society by observing and comprehending social types and predictions about that society. Actually, a social type represents an individual in a society. "As a powerful means of communication, cinema soon assumed the function of a 'document-in-itself', like photography" (Baker, 2002, p.63). Because photography has a motionless layout, it has a distance from real life. Unlike photography, cinematography increases the 'trace' character of the cinematic signs and creates an 'illusion of movement' (Baker, 2002, p. 63). Hence, we can express that cinema makes social types visible for us.

\section{Origins of social types in Turkish cinema}

History of Turkish Cinema officially starts in 1914 with "The Demolition of the Russian Monument at St Stephan" (Aya Stefanos'taki Bir Rus Abidesinin Yıkıllşı) documentary by Fuat Uzkınay. Turkish cinema, which has 103 years of history, has a historical and traditional connection with Turkish visual arts. Turkish visual arts come from a tradition that is based on Turkish traditional theatre. We can see representations of social types from the Turkish society of the era in all traditional Turkish theatre plays.

Turkish shadow play (Karagöz), theatre in the round (Orta Oyunu), stand alone shows (Meddah), puppetry, improvisational theatre (tuluat), village theatre and jugglery branches are among the Turkish traditional theatre plays (Ünver, 2009, pp. 13-14). If we look at Karagöz's characteristics, we can find parallelisms and similarities with Turkish cinema. Among the Turkish traditional theatre plays, Karagöz is the closest one to cinema (Ünver, 2009, p.127). The origins of Karagöz come from Egypt during the 16th century (And, 2010: 17). After its introduction from Egypt, Turks made their own contributions to shadow play and characters of Karagöz emerged (And, 2010, p. 21). Most of the knowledge on Karagöz plays dates from the late 19th century, and we learn that Karagöz plays consist of political satire (And, 2010, pp. 31-35). In the writings of a foreign observer, we see that "Karagöz spared no one in his harangues, whether pasha, ulema, dervish, banker or merchant, but that everyone of every class and every occupation made their 
Coşkun, Ç. (2017). Sociology in cinema: Origins of social types in Turkish cinema. International Journal of Social Sciences and Education Research,3 (4), 1147-1154.

appearance on the curtain, each identified by their distinctive characteristics and were sometimes obliged to very harsh truths," (And, 2010, p.37). Therefore, the characters of Karagöz are stereotypes of individuals in the society and include the general characteristics of those people (And, 2010, p. 41). Stereotypes are standardized conceptions of people that are based on an individual's belonging to a category or having some characteristics symbolizing one of these categories (Schweinitz, 2006, p. 4). The characteristics of Karagöz fit this definition. Social types are produced by the society and represent an individual in that society as we discussed above. Karagöz characters are types that were formed through generalizations of characteristics of individuals of the period.

After the invention of the cinematograph in 1895 by the L'umiere brothers in France, screenings were held in different cities of the world. In Istanbul, the first screening was made in a Karagöz screen in Fevziye Kıraathanesi in Şehzadebaşı towards the end of 1896 (Şener, 1970, p.9).Thus, Karagöz master Katip Salih Efendi's screen (Şener, 1970, p.9) made the first connection between cinema and Karagöz. There is more in common between cinema and Karagöz, however, than just a screen. Character types existed in both films and in Karagöz. Just as Karagöz characters represent general types of people in the society, characters in cinema also represent types in society in a sense. This identification with traditional arts caused a fast acceptance of cinema among people.

Fairytales, Meddah, Orta Oyunu, Tuluat, puppetry and other traditional arts are among the other sources of inspiration of Turkish cinema. For instance, scriptwriter Bülent Oran finds Turkish cinema's roots in Karagöz and the famous Turkish fairytale Keloğlan. According to him, the audience likes some film characters as they like Karagöz characters. When this character appears on the screen, they react according to character. If a character is a comic, the audience starts laughing, even if there is a dramatic scene (Türk, 2004, pp. 224, 225). If a character is dramatic, they do not laugh, even if the scene is comedy. On the other hand, Keloğlan is a poor character who lives with his mother in the fairytale. He falls in love with the Sultan's daughter, and he has to fight monsters and travel far away (Kafdağı in the fairytale) in order to marry her (Türk, 2004, p.199). He represents a poor and very smart peasant social type. Thus, we can state that origins of social types in Turkish cinema films are also come from traditional fairytales.

When we look at this Turkish cinema films from this traditional origin, we can see that there is a similar representation of social types in Turkish films. We can find a similar storyline in many Turkish films of the 1960-1975 period (Yeşilcam Filmleri in Turkish usage), the golden age of Turkish cinema. The dominant genre of the period is melodrama. "In a classical melodrama-melodrama based around a truly evil villain that victimizes an innocent, purely good soul- portrays emotional excess in the villain's expressions of hatred, envy, jealousy, spite, or malice," (Singer, 2001, p.39) In a classical melodrama plotline generally there are elements of "domestic location, familial conflict, the stock types of brave hero, evil villain, and suffering heroine, the struggle of good and evil, and plot motifs such as kidnap or seduction," (Flitterman-Lewis, 1994, p.11). If we apply this situation to a classical Turkish melodrama plot, generally a poor character falls in love with a rich character. They have to fight against the rich character's father/mother and encounter other difficulties in order to marry each other. Throughout the story secondary characters 
Coşkun, Ç. (2017). Sociology in cinema: Origins of social types in Turkish cinema. International Journal of Social Sciences and Education Research,3 (4), 1147-1154.

help them. This structure of melodrama is very fertile to represent social types. Similar to Karagöz or Meddah, types that we can see in the society are represented in Turkish Yeşilçam melodramas.

At that point, we should emphasize an important situation in Turkish cinema. There is a 'ruralurban' conflict or relationship in films that were produced during the 1950-1980 period in Turkish cinema. This conflict is, indeed, the major background in almost all Turkish films until today, since Turkish society lived a migration process from rural areas to urban areas between approximately 1950 and 1980. This migration process created a big social change in the country and so in cinema. Thus, a rural-urban conflict between the characters in films were created, which is similar to real life during the period. Actually, we see that there is a rural-urban conflict in all areas of life; and social inequalities were an agenda topic in this period (Abisel, 2005, p.203). Social problems of the country have surely affected cinema, and we watch this conflict in films. In a period in which traditional life started to evolve into a modern one, characters in films encountered social, economic, and identity problems. We watch this story line in a classical narrative structure along with main characters of a classical narrative: The hero, heroine and villain appear together with secondary characters and narrate a story that involves the rural-urban conflict. In a general storyline, the character comes from rural to a big city and faces with challenges in the modern city life. If the film is a comedy, the rural character solves problems with her/his rural entertaining sense; if the film is a melodrama, the character either learns to adapt the modern city conditions generally with the help of a modern, urbanized character or cannot cope with the difficulties of city life and loses. In these films, we watch various social types which can be found also in real life such as workers, singers, repairmen, housewives, thieves, servants, doormen etc.

In sum, we should state that origins of social types in Turkish cinema are parallel with the developments in the country and social types in society are represented in these films. Origins of this representation of social types in cinema are based on traditional Turkish visual arts and we see similar plots.

\section{Conclusion}

As we mentioned above, social types and narration in a film led the identification of the audience with the story and characters. That is the reason why we remember films in detail more than a didactical content. Besides, throughout sociological imagination, we can make the connection between social types in films and people in real life.

This situation is valid for Turkish cinema as well. If we look at the origins of social types in Turkish cinema, we can find out that the connection between social types and real life is in the roots of Turkish traditional arts and so in cinema. Although the cinema films are fictional products, they represent the social types in the Turkish society since they have a realistic manner. Therefore, we can use the story lines and characters of cinema films in order to understand Turkish society.

\section{References}

Abisel, N. (1995). Popüler Sinema ve Türler. İstanbul: Alan Yayınc1lık

And, M. (2010). Karagöz. Ed. D. Çevik. Trans. T. Kaan. Ankara: Kültür ve Turizm Bakanlığı Yayınları.

Almog, O. (1998) The Problem of Social Type: A Review. Electronic Journal of Sociology. https://www.sociology.org/content/vol003.004/almog.html\#26b 
Coşkun, Ç. (2017). Sociology in cinema: Origins of social types in Turkish cinema. International Journal of Social Sciences and Education Research,3 (4), 1147-1154.

Aristotle. (1997). Poetics. New York: Dover Publications.

Baker, U. (2002) From Opinion to Images. PhD Thesis.Middle East Technical University.

Balázs, B. (1952) Theory of the Film: Character and Growth of a New Art. Trans. Edith Bone. London: Dennis Dobson Ltd..

Barthes, R. (1974). S/Z. Trans. Richard Miller. New York: Hill and Wang.

Bartle, R. (1996). Heats, Clubs, Diamonds, Spades: Players Who Suit Muds. Retrieved from: https://www.researchgate.net/publication/247190693_Hearts_clubs_diamonds_spades_Players_who_suit_MUDs

Booth, B., Blair, M. (1989) Thesaurus of Sociological Indexing Terms. San Diego, CA: Sociological Abstracts Inc.

Bordwell, D., Thompson, K., (1988). The Classical Hollywood Cinema: Film Style and Mode of Production to 1960. London: Routledge.

Butler, J. Classical Narrative Structure: Exposition, Climax, Resolution. Critical Commons. Retrieved from http://www.criticalcommons.org/Members/jbutler/commentaries/ classical-narrative structure-exposition-climax-resolution.

Campbell, J., Fletcher, G. \& Greenhill, A. (2009). Conflict and Identity Shape Shifting in an Online Financial Community. Information Systems Journal 19 (5), 461-478.

Chatman, S. B. (1978). Story and Discourse: Narrative Structure in Fiction and Film. New York: Cornell University Pres.

Flitterman-Lewis, S. (1994). The Blossom and the Bole: Narrative and Visual Spectacle in Early Film Melodrama. Cinema Journal. 33 (3), 3-15 http://www.jstor.org/stable/1225585

Giddens, A. (1990). The Consequences of Modernity. Cambridge: Polity Press.

Glick, C.E. (1955). Social types in Race Relations. In A.W Lind. (Ed) Race Relations in World Perspective. Pp. 194-200. Oxford: Oxford University Press.

Goffman, E. (1959). The Presentation of Self In Everyday Life. New York: Doubleday.

Lévi-Strauss, C. (1955). The Structural Study of Myth. The Journal of American Folklore. 68.27, 428-444.

Mills, C. W. (1959). The Sociological Imagination. New York: Oxford University Press.

Olivier, B. (2009). Extra Ordinary Cinema. South African Journal of Art History. 24(1), 20-33.

Propp, V.I.A. (1969). Morphology of the Folk Tale. Texas: University of Texas Press.

Schweinitz, J. (2006). Film and Stereotype: A Challenge for Cinema and Theory. Trans. Laura Schleussner. New York: Columbia University Pres

Singer, B. (2001). Melodrama and Modernity: Early Sensational Cinema and Its Contexts. New York: Columbia University Pres.

Şener, E. (1970). Yeşilçam ve Türk Sineması. İstanbul: Kamera Yayınları.

Strong, M. S. (1943). Social Types in a Minority Group: Formulation of a Method. American Journal of Sociology 49, 563-573.

Tan, E. S. (1996). Emotion and the Structure of Narrative Film: Film as an Emotion Machine. Trans. Barbara Fasting. Mahwah and New Jersey.: Lawrence Erlbaum Associates.

Todorov T., Weinstein, A. (1969). Structural Analysis of Narrative. NOVEL: A Forum on Fiction. 3 (1), 70-76

Türk, İ. (2004). Senaryo Bülent Oran. İstanbul: Dergah Yayınları.

Ünver, O. (2009). Turkish Shadow Play/Karagöz. Trans. Cumhur Oranc1. Ankara: Ministry of Culture and Tourism Publications 